\title{
RESPON PERTUMBUHAN DAN PRODUKSI PADI (Oryza sativa L.) VARIETAS SULUTTAN UNSRAT 1 DENGAN METODE SRI TERHADAP PEMBERIAN PUPUK ANORGANIK DAN PUPUK HAYATI
}

\section{RESPONS OF GROWTH AND PRODUCTION OF SULUTTAN UNSRAT 1 VARIETIES RICE (Oryza sativa L) WITH SRI METHOD AGAINST GRANTING IN ORGANIC FERTILIZERS AND BIOFERTILIZERS}

\author{
Leonardie Wellem Ratela1), Jeany Sh. Polii-Mandang2), dan Jeanne M. Paulus ${ }^{2)}$ \\ 1)Badan Pelaksana Penyuluhan Pertanian, Perikanan dan Kehutanan Kabupaten Minahasa Tenggara \\ 2)Fakultas Pertanian Unsrat Manado, 95115 \\ e-mail : leoratela@yahoo.co.id
}

\begin{abstract}
This research aims to study the response of growth and yield of paddy rice to the combination of inorganic fertilizer and biological fertilizers. The design of experiments used in this study is a single factor in a completely randomized design (CRD), which consists of 5 treatments and repeated 5 times with the treatment as follows: P0 $=100 \%$ NPK (control) P1 $=100 \%$ NPK $+100 \%$ Biofertilizer Petrobio, P2 $=75 \%+25 \%$ NPK Fertilizer Biological Petrobio, P3 $=50 \%+50 \%$ NPK Fertilizer Biological Petrobio, P4 $=25 \%+75 \%$ NPK Fertilizer Biological Petrobio. Giving Phonska inorganic fertilizer mixed with the biological fertilizer petrobio influence on the growth and yield of rice varieties Suluttan Unsrat I. Treatment NPK fertilizer Phonska $75 \%$ and $25 \%$ of biological fertilizers petrobio produce an average plant height is $98.40 \mathrm{~cm}$ high, $24.40 \mathrm{~cm}$ panicle length , Total grain permalai 167 grains, grain pithy permalai Total 155.20 grains and weight of 1000 grains contain.

Key words: rice paddy fields, of SRI (System of Rice Intensification), inorganic fertilizers, biofertilizers
\end{abstract}

\begin{abstract}
ABSTRAK
Penelitian ini bertujuan untuk mengkaji respons pertumbuhan dan produksi tanaman padi sawah terhadap kombinasi pemberian pupuk anorganik dan pupuk hayati. Rancangan Percobaan yang digunakan dalam penelitian ini adalah faktor tunggal dalam Rancangan Acak Lengkap (RAL) yang terdiri atas 5 perlakuan dan diulang sebanyak 5 kali dengan perlakuan sebagai berikut: P0 $=100 \%$ NPK (control) P1 $=100 \%$ NPK + $100 \%$ Pupuk Hayati Petrobio, P2 $=75 \%$ NPK $+25 \%$ Pupuk Hayati Petrobio, P3 $=50 \%$ NPK $+50 \%$ Pupuk Hayati Petrobio, P4 $=25 \%$ NPK $+75 \%$ Pupuk Hayati Petrobio. Pemberian pupuk anorganik Phonska yang dicampur dengan pupuk hayati petrobio memberikan pengaruh terhadap pertumbuhan dan produksi tanaman padi varietas Suluttan Unsrat I. Perlakuan $75 \%$ pupuk NPK phonska dan $25 \%$ pupuk hayati petrobio menghasilkan rata-rata tinggi tanaman tertinggi yaitu $98.40 \mathrm{~cm}$, panjang malai $24.40 \mathrm{~cm}$, jumlah gabah per malai 167 butir, jumlah gabah bernas per malai 155.20 butir dan berat 1000 butir gabah berisi.

Kata kunci: padi sawah, metode SRI (System of Rice Intensification), pupuk anorganik, pupuk hayati
\end{abstract}




\section{PENDAHULUAN}

\section{Latar Belakang}

Tantangan pembangunan pertanian di masa mendatang adalah penyediaan pangan bagi penduduk yang lebih dikenal dengan istilah ketahanan pangan. Menurut Lembaga Penelitian UGM (2014), pangan merupakan komoditas penting dan strategis bagi bangsa Indonesia mengingat pangan adalah kebutuhan dasar manusia yang harus dipenuhi oleh pemerintah dan masyarakat secara bersama-sama seperti diamanatkan oleh Undang Undang Nomor 7 tahun 1996 tentang pangan.

Upaya khusus pemerintah untuk swasembada pangan pada tahun 2017 berkaitan erat dengan peningkatan produksi padi sawah. Peningkatan produksi padi menghadapi tantangan yang makin berat, karena selain peningkatan kebutuhan akibat meningkatnya jumlah penduduk juga disebabkan makin menciutnya lahan sawah produktif karena alih fungsi lahan, terbatasnya lahan subur, ancaman iklim serta kasus-kasus serangan hama dan penyakit tanaman (Fagi, dkk., 2002).

Dalam upaya efisiensi penggunaan pupuk anorganik khususnya Nitrogen, Phospat dan Kalium pada pertanaman padi adalah dengan pemanfaatan pupuk hayati. Pupuk hayati ialah bahan yang mengandung mikroorganisme hidup dari mikrobia yang digunakan untuk meningkatkan jumlah mikrobia sehingga dapat menambah ketersediaan unsur hara bagi tanaman (Sugito, et. al., 1995 dalam Wahyuni, 2012). Pupuk Petrobio ialah pupuk hayati yang berbahan aktif bakteri penambat $\mathrm{N}$ bebas non simbiotik dan mikroba pelarut Phospat.

Berdasarkan hal tersebut maka diperlukan upaya untuk meningkatkan hasil produksi tanaman padi sawah dengan menggunakan pupuk anorganik dengan pupuk hayati. Pupuk hayati yang akan digunakan dalam penelitian ini adalah pupuk hayati Petrobio.

Penelitian ini bertujuan untuk mengkaji respons pertumbuhan dan produksi tanaman padi sawah terhadap kombinasi pemberian pupuk anorganik dan pupuk hayati. Diharapkan Penelitian ini dapat memberikan informasi dan data tentang kombinasi yang tepat antara pupuk anorganik dan pupuk hayati yang dapat meningkatkan pertumbuhan dan produksi tanaman padi sawah di Kabupaten Minahasa Tenggara Provinsi Sulawesi Utara.

\section{METODE PENELITIAN}

Penelitian ini dilaksanakan di Desa Molompar Satu Kecamatan Tombatu Timur dengan ketinggian tempat $500 \mathrm{~m}$ dpl. Waktu pelaksanaan di lapangan selama 4 bulan sejak bulan Desember 2015 sampai dengan Maret 2016.

Bahan yang digunakan : Benih Padi varietas Suluttan Unsrat 1, Pupuk Hayati Petrobio, Pupuk NPK Phonska serta Pestisida. Alat yang digunakan : Cangkul, Hand Traktor, Hand Sprayer, ajir, tali, wadah plastik, timbangan analitis, karung/ kantong plastik, meteran dan alat tulis menulis.

\section{Metode penelitian}

Penelitian ini merupakan percobaan faktor tunggal dalam Rancangan Acak Lengkap (RAL) yang terdiri atas 5 perlakuan dan diulang sebanyak 5 kali dengan perlakuan sebagai berikut:

$\mathrm{P0}=100 \%$ NPK (control)

P1 $=100 \%$ NPK $+100 \%$ Pupuk Hayati Petrobio.

P2 $=75 \%$ NPK $+25 \%$ Pupuk Hayati Petrobio

P3 $=50 \%$ NPK $+50 \%$ Pupuk Hayati Petrobio

P4 $=25 \%$ NPK $+75 \%$ Pupuk Hayati Petrobio

\section{Analisis Data}

Data yang diperoleh dianalisis dengan analisis sidik ragam dan jika terdapat perbedaan yang nyata akan dilanjutkan dengan uji BNT (Beda Nyata Terkecil).

\section{Variabel yang Diamati}

Tinggi tanaman $(\mathrm{cm})$, jumlah anakan produktif, panjang malai $(\mathrm{cm})$, jumlah gabah per malai, jumlah gabah bernas per malai, bobot 1000 butir gabah kering giling (GKG) (gram), Berat Gabah Kering Panen (Kg/Petak).

\section{Prosedur Kerja Persiapan Lahan}

Sebelum ditanami lahan yang akan digunakan diolah terlebih dahulu. Pengolahan tanah dilakukan sebanyak dua kali dengan cara dibajak 
menggunakan hand traktor. Pengolahan tanah pertama dilakukan pembalikan tanah agar gulma dan sisa tanaman sebelumnya bisa mengendap di dalam tanan, kemudian dilanjutkan dengan penggaruan atau pemerataan tanah.

\section{Persemaian}

Benih yang akan digunakan direndam terlebih dahulu dalam larutan garam guna memisahkan benih yang terisi penuh dengan yang setengah terisi dan benih hampa. Sesudah itu direndam selama 24 jam kemudian dihamparkan dan dibungkus dikarung basah sampai muncul bakal lembaga berupa bintik putih pada bagian ujungnya. Benih disebar pada wadah plastik yang sudah disiapkan

\section{Penanaman}

Penanaman dilakukan pada kondisi lahan dalam keadaan tidak tergenang atau macak-macak. Jarak tanam yang digunakan $30 \times 30 \mathrm{~cm}$ dengan luasan lahan tiap petak $3 \times 4 \mathrm{~m}\left(12 \mathrm{~m}^{2}\right)$. Setiap lobang berjumlah satu bibit. Umur bibit saat tanam adalah 10 hari.

\section{Penyiangan}

Penyiangan dilakukan sesuai dengan keadaan gulma yang ada disawah tempat penelitan.

\section{Pemupukan}

Pada penelitian ini pupuk yang digunakan adalah pupuk hayati dan pupuk anorganik. Untuk pupuk hayati jenis yang digunakan adalah pupuk hayati petrobio yang diberikan pada lahan padi saat tanam. Sedangkan pupuk anorganik yang digunakan adalah pupuk majemuk NPK Phonska.

Pupuk anorganik yang dicampur dengan pupuk hayati sesuai dengan perlakuan pada penelitian (5 perlakuan), yang ada diaplikasikan 3 kali yaitu pertama $40 \%$, kedua $30 \%$ dan ketiga $30 \%$ dari dosis. Dosis pupuk NPK Phonska $300 \mathrm{Kg} / \mathrm{Ha}$ dan Pupuk Hayati $50 \mathrm{Kg} / \mathrm{Ha}$.

\section{Pemeliharaan \\ Pengairan}

Pengairan dilakukan secara rutin sesuai dengan kebutuhan tanaman. Pada awal tanam, air di petakan sawah dalam keadaan macak-macak, selanjutnya diatur secara berselang

\section{Pemberantasan Hama dan Penyakit}

Pengendalian hama dan penyakit tanaman dilakukan melalui pengamatan secara visual di lapangan dan mengidentifikasi OPT dan gejala serangannya sehingga dapat dilakukan pengendalian secara mekanik maupun kimia (menggunakan pestisida).

\section{Panen}

Pemanenan dilakukan dengan melihat keadaan gabah yaitu setelah mencapai kurang lebih $90 \%$ masak fisiologis dengan gabah kuning $80 \%$ atau lebih.

\section{HASIL DAN PEMBAHASAN}

\section{Tinggi Tanaman}

Hasil pengamatan terhadap tinggi tanaman padi sawah varietas Suluttan Unsrat 1, menunjukkan bahwa perlakuan pemupukan dengan $50 \%$ NPK dan $50 \%$ Pupuk Hayati (P3) memberikan hasil rata-rata tinggi tanaman terendah $(91,0 \mathrm{~cm})$, sedangkan pemupukan dengan $75 \%$ NPK dan $25 \%$ Pupuk Hayati (P2) memberikan hasil ratarata tinggi tanaman tertinggi $(98,4 \mathrm{~cm})$.

Berdasarkan hasil analisis sidik ragam BNT $(0,05)$ sebagaimana yang disajikan pada Tabel 1 diperoleh data bahwa pengaruh pemberian $75 \%$ NPK dan $25 \%$ Pupuk Hayati (P2) menghasilkan rata-rata tinggi tanaman tertinggi yaitu $98.40 \mathrm{~cm}$ dan dalam uji statistik menunjukkan tidak ada perbedaan yang nyata antara perlakuan. 
Tabel 1. Pengaruh Pemupukan Anorganik dan Pupuk Hayati terhadap Tinggi Tanaman Padi Sawah

(Table 1. Effect of Chemical Fertilizers and Biological Fertilizers to the Plant Height of Paddy)

\begin{tabular}{ccc}
\hline Perlakuan & Tinggi Tanaman & Notasi \\
\hline$\ldots \ldots \ldots \ldots$. Kg ......... & $\ldots . . c m \ldots \ldots$ & \\
P2 (75\% NPK dan 25 \% Hayati) & 98.40 & $\mathrm{a}$ \\
P1 (100\% NPK dan 100 \% Hayati) & 94.60 & $\mathrm{a}$ \\
P0 (100\% NPK ) & 94.20 & $\mathrm{a}$ \\
P4 (25\% NPK dan 75 \% Hayati) & 91.80 & $\mathrm{a}$ \\
P3 (50\% NPK dan 50 \% Hayati) & 91.00 & $\mathrm{a}$ \\
\hline BNT $(0,05)$ & 5.92 & \\
\hline
\end{tabular}

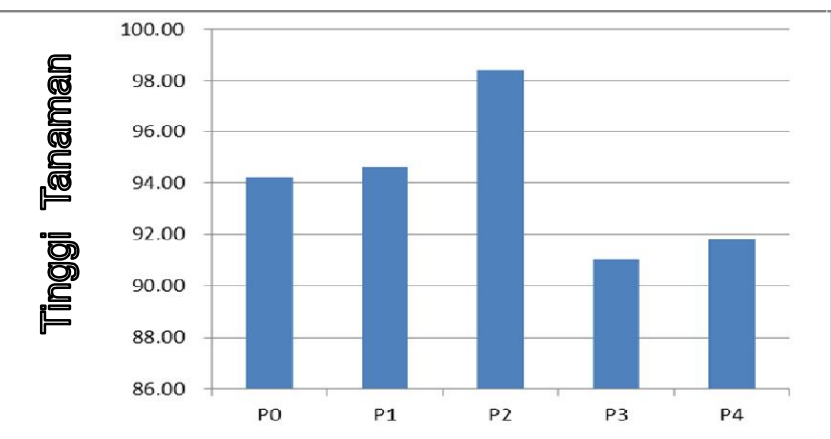

Gambar 1. Pengaruh Pemberian Pupuk Anorganik dan Pupuk Hayati Terhadap Tinggi Tanaman

(Figure 1. Effect of Chemical Fertilizers and Biological Fertilizers to the Plant Height of Paddy)

Gambar 1 menunjukkan bahwa penggunaan pupuk anorganik dan pupuk hayati Petrobio tidak memberikan pengaruh yang nyata terhadap tinggi tanaman, pada perlakuan $75 \%$ pupuk NPK dan $25 \%$ pupuk Petrobio memberikan hasil tertinggi. Adanya pengaruh yang nyata pada penggunaa NPK $75 \%$ dan pupuk Petrobio $25 \%$, menunjukkan bahwa padi varietas Suluttan Unsrat sangat responsif terhadap pemupukan NPK terutama unsur $\mathrm{N}$ yang dibutuhkan pada fase awal pertumbuhan. Pada takaran NPK Phonska $75 \%$ yang dicampur dengan Petrobio $25 \%$ semakin tinggi pertumbuhan tinggi tanaman disebabkan karena pada dasarnya Petrobio berperan dalam mengefektifkan pupuk kimia terutama $\mathrm{N}$ dan $\mathrm{P}$.

\section{Jumlah Anakan Produktif}

Hasil pengamatan terhadap jumlah anakan produktif padi sawah varietas Suluttan Unsrat 1 , menunjukkan bahwa perlakuan pemupukan dengan $50 \%$ NPK dan $50 \%$ Pupuk Hayati (P3) memberikan hasil rata-rata anakan produktif terendah $(18,6$ anakan/rumpun), sedangkan pemupukan dengan
$25 \%$ NPK dan $75 \%$ Pupuk Hayati (P4) memberikan hasil rata-rata anakan tertinggi (24,4 anakan/ rumpun).

Berdasarkan hasil analisa sidik ragam BNT $(0,05)$ sebagaimana yang disajikan pada Tabel 2 tidak menunjukkan perbedaan yang nyata, pengaruh pupuk anorganik yang dicampur dengan pupuk hayati terhadap jumlah anakan produktif padi sawah varietas Suluttan Unsrat I menunjukan bahwa perlakuan pemupukan dengan $50 \%$ NPK dan $50 \%$ Pupuk Hayati (P3) memberikan hasil rata-rata anakan produktif terendah (18,6 anakan/ rumpun), sedangkan pemupukan dengan $25 \%$ NPK dan 75 \% Pupuk Hayati (P4) memberikan hasil rata-rata anakan tertinggi (24,4 anakan/ rumpun), sebagaimana terlihat pada Gambar 2, meskipun dalam analisi sidik ragam BNT $(0,05)$.

Gambar 2 menunjukkan bahwa aplikasai pupuk NPK dan pupuk hayati petrobio dalam berbagai perlakuan sangat baik diberikan pada lahan sawah. Hal ini membuktikan bahwa pada masa pertumbuhan vegetatif tanaman membutuhkan $\mathrm{N}$ yang tinggi. Keberadaan pupuk hayati dalam tanah 
sangat efektif karena dapat meningkatkan ketersediaan hara dan memperbaiki sifat tanah dalam mendukung pertumbuhan tanaman.

\section{Panjang Malai}

Berdasarkan hasil analisis statistik terhadap panjang malai padi sawah menunjukan tidak adanya perbedaan yang nyata pada semua perlakuan.

Hasil uji BNT $(0,05)$ sebagaimana yang disajikan pada Tabel 3, tidak menunjukkan perbedaan yang nyata. Berdasarkan hasil analisis statistik terhadap panjang malai padi sawah menunjukkan tidak adanya perbedaan yang nyata pada semua perlakuan.

Tabel 2. Pengaruh Pemupukan Anorganik dan Pupuk Hayati terhadap Jumlah Anakan Produktif Tanaman Padi Sawah

(Table 2. Effect of Chemical Fertilizers and Biological Fertilizers on the Number of Productive Tillers Rice Crops

\begin{tabular}{rcc}
\hline \multicolumn{1}{c}{ Perlakuan } & Jumlah Anakan Produktif & Notasi \\
\hline$\ldots \ldots \ldots . .$. Kg.......... & ....JAP/Rumpun...... & \\
P4 (25\% NPK dan 75 \% Hayati) & 24.40 & $\mathrm{a}$ \\
P2 (75\% NPK dan 25 \% Hayati) & 23.60 & $\mathrm{a}$ \\
P0 (100\% NPK ) & 21.40 & $\mathrm{a}$ \\
P1 (100\% NPK dan 100 \% Hayati) & 21.00 & $\mathrm{a}$ \\
P3 (50\% NPK dan 50 \% Hayati) & 18.60 & $\mathrm{a}$ \\
\hline BNT $(0,05)$ & 6.67 & \\
\hline
\end{tabular}

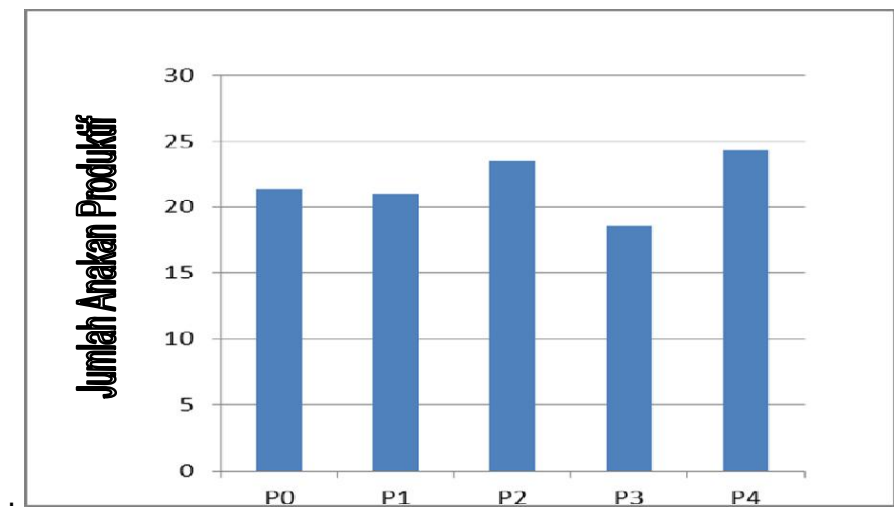

Gambar 2. Pengaruh Pemberian Pupuk Anorganik dan Pupuk Hayati Terhadap Jumlah Anakan Produktif

(Figure 2. Effect of Chemical Fertilizers and Biological Fertilizers on the Number of Productive Tillers Rice Crops)

Tabel 3. Pengaruh Pemupukan Anorganik dan Pupuk Hayati terhadap Panjang Malai Tanaman Padi Sawah (Table 3. Effect of Chemical Fertilizers and Biological Fertilizers on Long Panicles of Rice Crops)

\begin{tabular}{ccc}
\hline Perlakuan & Panjang Malai & Notasi \\
\hline$\ldots \ldots \ldots .$. Kg......... & $\ldots . . \mathrm{cm} \ldots \ldots$ & \\
P2 (75\% NPK dan 25 \% Hayati) & 24.40 & $\mathrm{a}$ \\
P1 (00\% NPK dan 100 \% Hayati) & 24.40 & $\mathrm{a}$ \\
P4 (25\% NPK dan 75 \% Hayati) & 24.00 & $\mathrm{a}$ \\
P0 (100\% NPK dan 100 \% Hayati) & 23.80 & $\mathrm{a}$ \\
P3 (50\% NPK dan 50 \% Hayati) & 23.40 & $\mathrm{a}$ \\
\hline BNT $(0,05)$ & 1.06 & \\
\hline
\end{tabular}


Gambar 3 menunjukkan bahwa perlakuan P1 dan P2 memberikan respons yang sama terhadap panjang malai yang dihasilkan jika dibandingkan dengan perlakuan yang lain. Kedua perlakuan ini menghasilkan panjang malai yang lebih tinggi, ini disebabkan karena penggunaan pupuk hayati selain bermanfaat untuk mengaktifkan serapan hara oleh tanaman sehingga meningkatkan pertumbuhan tanaman juga berdampak terhadap peningkatan produksi tanaman.

\section{Jumlah Gabah per Malai}

Hasil pengamatan terhadap jumlah gabah per malai tanaman padi sawah, menunjukkan bahwa perlakuan pemupukan dengan $25 \%$ NPK dan $75 \%$ Pupuk Hayati (P3) memberikan hasil rata-rata jumlah gabah per malai tanaman terendah (152.20 butir/malai), sedangkan pemupukan dengan 75 \% NPK dan 25 \% Pupuk Hayati (P2) memberikan hasil rata-rata jumlah gabah per malai tanaman terbanyak (167 butir).

Berdasarkan hasil analisa sidik ragam BNT $(0,05)$ sebagaimana yang disajikan pada tabel 4 , tidak menunjukkan perbedaan yang nyata antar semua perlakuan.

Gambar 4 menunjukkan penggunaan pupuk anorganik $75 \%$ dan Pupuk Hayati $25 \%$ memberikan hasil yang baik. Anonim (2012) menambahkan bahwa Pupuk hayati petrobio berisi mikroorganisme penghancur bahan-bahan organik (dekomposer) sehingga tanah menjadi gembur, sehingga mampu menahan air yang lebih banyak dan akar tanaman dapat berkembang lebih maksimal, sehingga serapan unsur hara akan lebih efektif, yang akhirnya meningkatkan pertumbuhan dan produksi tanaman.

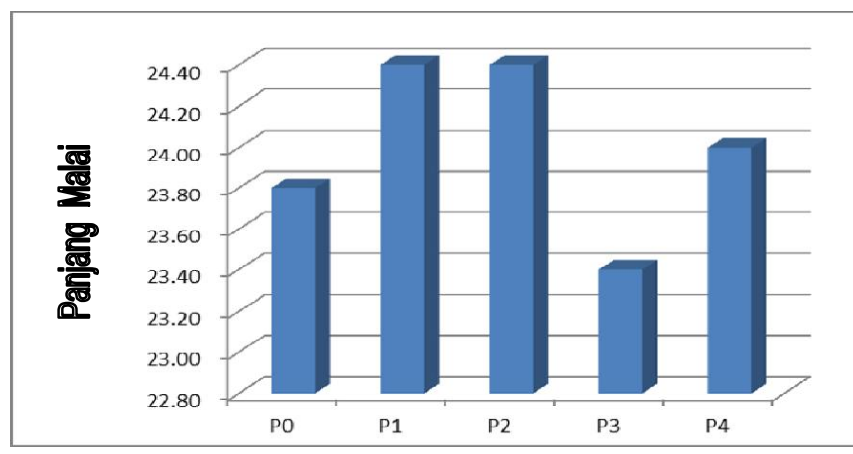

Gambar 3. Pengaruh Pemberian Pupuk anorganik dan Pupuk Hayati Terhadap Panjang Malai

(Figure 3. Effect of Chemical Fertilizers and Biological Fertilizers on Long Panicles of Rice Crops)

Tabel 4. Pengaruh Pemupukan Anorganik dan Pupuk Hayati terhadap Jumlah Gabah Per Malai Tanaman Padi Sawah

(Table 4. Effect of Chemical Fertilizers and Biological Fertilizers on the Number of Grains Panicle Rice Crops)

\begin{tabular}{rcc}
\hline \multicolumn{1}{c}{ Perlakuan } & Jumlah Gabah Permalai & Notasi \\
\hline$\ldots \ldots \ldots . .$. Kg......... & $\ldots$. butir...... & \\
P2 (75\% NPK dan 25 \% Hayati) & 167.00 & a \\
P0 (100\% NPK ) & 164.40 & a \\
P1 (00 \% NPK dan 100 \% Hayati) & 160.80 & a \\
P3 (50\% NPK dan 50 \% Hayati) & 152.40 & a \\
P4 (25\% NPK dan 75 \% Hayati) & 152.20 & a \\
\hline BNT $(0,05)$ & 17.09 & \\
\hline
\end{tabular}




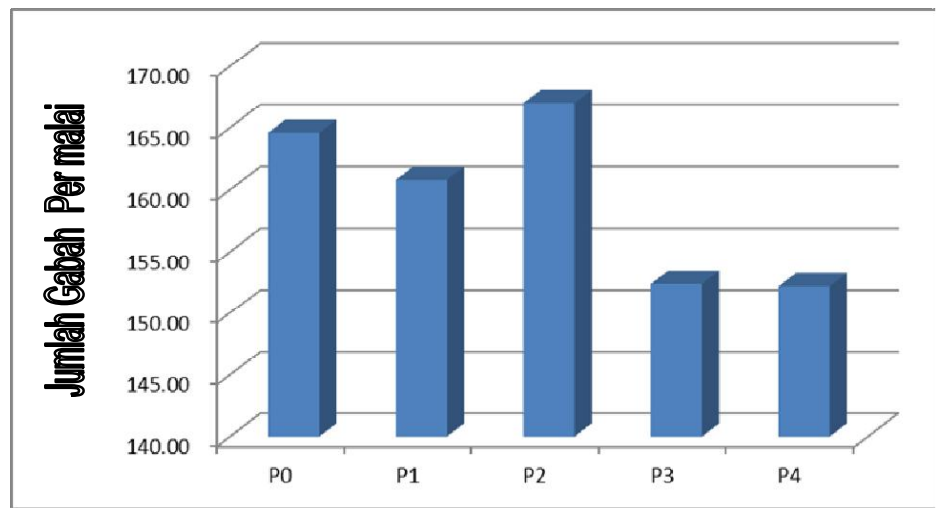

Gambar 4. Pengaruh Pemberian Pupuk Anorganik dan Pupuk Hayati Terhadap Gabah Per Malai

(Figure 4. Effect of Chemical Fertilizers and Biological Fertilizers on the Number of Grains Panicle Rice Crops)

\section{Jumlah Gabah Bernas Per Malai}

Hasil pengamatan terhadap jumlah gabah bernas per malai tanaman padi sawah, menunjukkan bahwa perlakuan pemupukan dengan $25 \%$ NPK dan $75 \%$ Pupuk Hayati (P4) memberikan hasil rata-rata jumlah gabah per malai tanaman terendah (138.20 butir/malai), sedangkan pemupukan dengan $75 \%$ NPK dan $25 \%$ Pupuk Hayati (P2) memberikan hasil rata-rata jumlah gabah per malai tanaman terbanyak (155.20 butir/malai).

Berdasarkan hasil analisa sidik ragam BNT $(0,05)$ sebagaimana yang disajikan pada Tabel 5 , diperoleh data bahwa pengaruh pemberian $75 \%$ NPK dan $25 \%$ Pupuk Hayati (P2) menghasilkan rata-rata jumlah gabah per malai paling banyak yaitu 155,20 butir/malai, dalam uji statistik menunjukkan perbedaan yang nyata antar perlakuan P2, perlakuan P3 dan Perlakuan P4.

Gambar 5 menunjukkan bahwa perlakuan pemupukan dengan $25 \%$ NPK dan $75 \%$ Pupuk Hayati (P4) memberikan hasil rata-rata jumlah gabah per malai tanaman terendah (138.20 butir/ malai), sedangkan pemupukan dengan $75 \% \mathrm{NPK}$ dan $25 \%$ Pupuk Hayati (P2) memberikan hasil rata-rata jumlah gabah per malai tanaman terbanyak (155.20 butir/malai).

Hasil analisa sidik ragam BNT $(0,05)$ menunjukkan perbedaan yang nyata antar perlakuan P2, perlakuan P3 dan Perlakuan P4. Dengan ketersediaan nutrisi yang cukup pada tanaman memacu pertumbuhan akar dan pembentukkan sistem perakaran tanaman yang baik sehingga tanaman dapat mengambil unsur hara lebih banyak. Ter- sedianya unsur hara yang cukup akan memacu pembentukan bunga dan memperbesar presentase bunga jadi. Hal ini terjadi karena selain memperbaiki struktur tanah, tanaman mudah menyerap unsur hara di dalam tanah dan meningkatkan kandungan hara di dalam tanah.

\section{Berat 1000 Butir Gabah Berisi}

Hasil pengamatan terhadap berat 1000 butir padi, menunjukan bahwa perlakuan pemupukan dengan $50 \%$ NPK dan 50 \% Pupuk Hayati (P3) memberikan hasil rata-rata berat 1000 butir padi terendah (28,60 gram), sedangkan pemupukan $\mathrm{P0}$, P1, P2 dan P4 memberikan hasil berat 100 butir padi (28,80 gram).

Berdasarkan hasil analisa sidik ragam BNT $(0,05)$ terhadap berat 1000 butir padi berisi menunjukkan tidak ada perbedaan yang nyata pada semua perlakuan sebagaimana dapat dilihat pada tabel 6.

Perlakuan pemupukan dengan $50 \%$ NPK dan $50 \%$ Pupuk Hayati (P4) memberikan hasil rata-rata berat 1000 butir padi terendah $(28,60$ gram), sedangkan pemupukan P0, P1, P2 dan P4 memberikan hasil berat 100 butir padi (28,80 gram) hal tersebut dapat dilihat pada Gambar 6 .

Berdasarkan hasil analisa sidik ragam BNT $(0,05)$ terhadap berat 1000 butir padi berisi menunjukkan tidak ada perbedaan yang nyata pada semua perlakuan. Adanya pengaruh yang tidak nyata pada Petrobio lebih disebabkan karena pada dasarnya Petrobio lebih berperan dalam mengefektifkan pupuk kimia terutama $\mathrm{N}$ dan $\mathrm{P}$. 
Tabel 5. Pengaruh Pemupukan Anorganik dan Pupuk Hayati Terhadap Jumlah Gabah Bernas Per Malai Tanaman Padi Sawah

(Table 5. Effect of Chemical Fertilizers and Biological Fertilizers on the Number of Pithy Panicle Grain Rice Crops)

\begin{tabular}{|c|c|c|}
\hline Perlakuan & Jumlah Gabah Bernas per Malai & Notasi \\
\hline.. $\mathrm{Kg} \ldots \ldots \ldots$ & ....butir....... & \\
\hline P2 (75\% NPK dan $25 \%$ Hayati) & 155.20 & a \\
\hline P0 (100 \% NPK ) & 151.00 & $a b$ \\
\hline P1 (100 \% NPK dan $100 \%$ Hayati) & 148.80 & $a b$ \\
\hline P3 (50\% NPK dan $50 \%$ Hayati) & 138.60 & $\mathrm{~b}$ \\
\hline P4 (25\% NPK dan $75 \%$ Hayati) & 138.20 & b \\
\hline BNT $(0,05)$ & 2.12 & \\
\hline
\end{tabular}

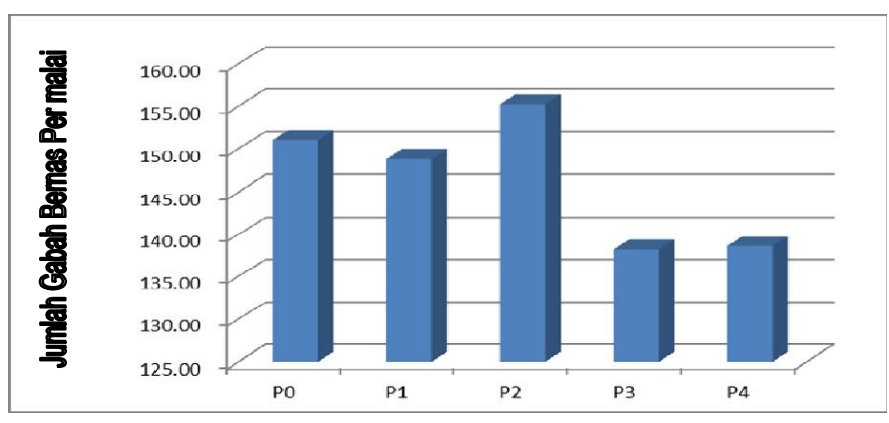

Gambar 5. Pengaruh Pemberian Pupuk anorganik dan Pupuk Hayati Terhadap Gabah Bernas Per Malai

(Figure 5. Effect of Chemical Fertilizers and Biological Fertilizers on the Number of Pithy Panicle Grain Rice Crops)

Tabel 6. Pengaruh Pemupukan Anorganik dan Pupuk Hayati Terhadap Berat 1000 Butir Padi

(Table 6. Effect of Chemical Fertilizers and Biological Fertilizers to the Weight of 1000 Grains of Rice)

\begin{tabular}{ccc}
\hline \multicolumn{1}{c}{ Perlakuan } & Berat 1000 Butir Padi & Notasi \\
\hline$\ldots \ldots \ldots .$. Kg.......... & $\ldots$. gram...... & \\
P0 (100 \% NPK $)$ & 28.80 & a \\
P1 (100\% NPK dan 100 \% Hayati) & 28.80 & a \\
P2 (75\% NPK dan 25 \% Hayati) & 28.80 & a \\
P4 (25\% NPK dan 75 \% Hayati) & 28.80 & a \\
P3 (50\% NPK dan 50 \% Hayati) & 28.60 & a \\
\hline BNT $(0,05)$ & 2.12 & \\
\hline
\end{tabular}

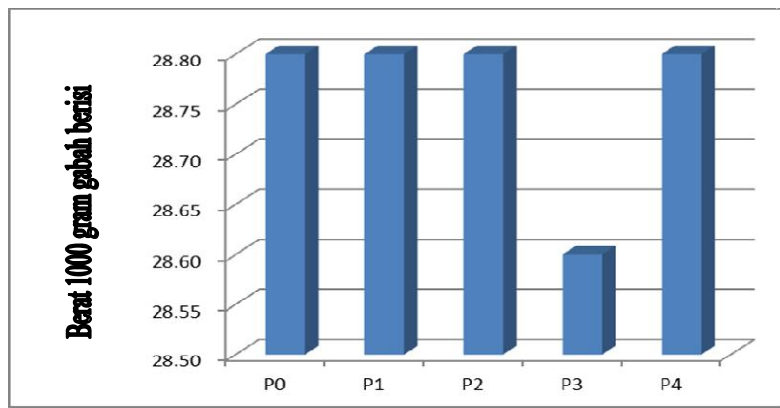

Gambar 6. Pengaruh Pemberian Pupuk anorganik dan Pupuk Hayati Terhadap Berat 1000 Gabah Berisi

(Figure 6. Effect of Chemical Fertilizers and Biological Fertilizers to the Weight of 1000 Grains of Rice) 


\section{Berat Gabah Kering Panen / Petak}

Hasil pengamatan terhadap berat gabah kering panen (GKP) perpetak dengan luasan $3 \times 4$ $\mathrm{m}$, menunjukan bahwa perlakuan pemupukan dengan 50 \% NPK dan 50 \% Pupuk Hayati (P3) memberikan hasil rata-rata berat GKP padi terendah $(5,97 \mathrm{Kg})$, sedangkan pemupukan pemupukan dengan $100 \%$ NPK dan 100 \% Pupuk Hayati (P1) memberikan hasil berat GKP padi tertinggi $(6,95 \mathrm{Kg})$. Data pada Tabel 7 merupakan hasil pengamatan gabah kering panen per petak.

Hasil uji BNT $(0,05)$ sebagaimana yang disajikan pada Tabel 7 diperoleh data bahwa pupuk NPK $100 \%$ dan 100\% Pupuk Hayati Perlakuan (P1) menghasilkan rata-rata Gabah Kering Panen terberat yaitu $6.95 \mathrm{~kg}$ per petak, meskipun dalam uji statistik tidak menunjukkan perbedaan yang nyata. Hasil pengamatan terhadap berat Gabah Kering Panen (GKP) per petak dengan luasan $3 \times 4 \mathrm{~m}$, menunjukkan bahwa perlakuan pemupukan dengan $50 \%$ NPK dan $50 \%$ Pupuk Hayati (P3) memberikan hasil rata-rata berat GKP padi terendah $(5,97$ $\mathrm{Kg}$ ), sedangkan pemupukan pemupukan dengan $100 \%$ NPK dan 100 \% Pupuk Hayati (P1) memberikan hasil berat GKP padi tertinggi $(6,95 \mathrm{Kg})$.

Hasil uji BNT $(0,05)$ tidak menunjukkan perbedaan yang nyata. Peningkatan GKP Pada perlakuan $\mathrm{P} 1$ disebakan karena pupuk hayati mengandung mikroorganisme hidup yang berfungsi sebagai inokulan untuk membantu menyediakan unsur hara bagi tanaman yang dapat memacu pertumbuhan tanaman sehingga tanaman padi tumbuh dengan baik dan menghasilkan gabah yang lebih banyak. Keberadaan pupuk hayati dalam tanah sangat efektif karena dapat meningkatkan ketersediaan hara dan memperbaiki sifat tanah dalam mendukung pertumbuhan tanaman.

Tabel 7. Pengaruh Pemupukan Anorganik dan Pupuk Hayati terhadap Gabah Kering Panen / Petak

(Table 7. Effect of Chemical Fertilizers and Biological Fertilizers to Dry Grain Harvest / Plot)

\begin{tabular}{|c|c|c|}
\hline Perlakuan & Gabah Kering Panen & Notasi \\
\hline .............Kg.......... & $\ldots . \mathrm{Kg} \ldots \ldots$ & \\
\hline P0 (100 \% NPK) & 6.72 & a \\
\hline P1 (100 \% NPK dan $100 \%$ Hayati) & 6.95 & a \\
\hline P2 (75\% NPK dan $25 \%$ Hayati) & 6.32 & a \\
\hline P4 (25\% NPK dan $75 \%$ Hayati) & 6.27 & a \\
\hline P3 (50\% NPK dan $50 \%$ Hayati) & 5.96 & a \\
\hline BNT $(0,05)$ & 2.12 & \\
\hline
\end{tabular}

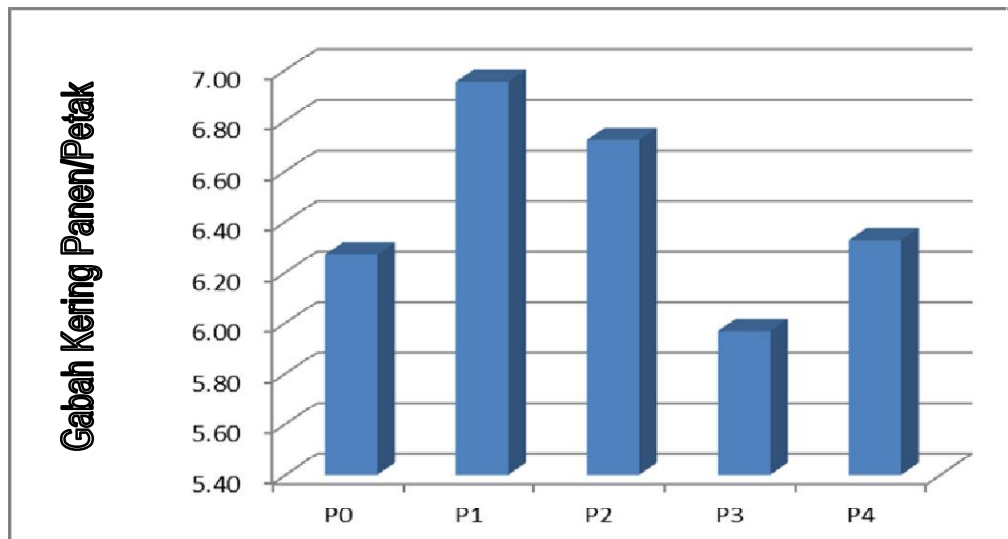

Gambar 7. Pengaruh Pemberian Pupuk anorganik dan Pupuk Hayati Terhadap Gabak Kering Panen/Petak (Figure 7. Effect of Chemical Fertilizers and Biological Fertilizers to Dry Grain Harvest / Plot) 


\section{KESIMPULAN DAN SARAN}

\section{Kesimpulan}

Berdasarkan hasil penelitian yang telah dilakukan, maka pemberian pupuk anorganik NPK yang dicampur dengan pupuk hayati tidak mempengaruhi pertumbuhan dan produksi padi Suluttan Unsrat 1. Penggunaan pupuk hayati dapat menghemat sampai $75 \%$ pupuk anorganik NPK.

\section{Saran}

Dalam rangka meningkatkan produksi padi sawah dengan metode SRI dianjurkan untuk menggunakan pupuk anorganik yang dicampur dengan pupuk hayati.

\section{DAFTAR PUSTAKA}

Anonim. 2012. Pupuk Petro Bio GR. Https:/l Saranaagri.Wordpress.Com/2012/12/12/P etrobio-Grl (Diakses Tgl 19 Mei 2015).
Fagi, A.H., I. Las dan M. Syam. 2002. Penelitian Padi menjawab Tantangan Ketahanan Pangan Nasional. Badan Penelitian dan Pengembangan Pertanian. Jakarta.

Kementerian Pertanian RI. 2004. Perencanaan Program Ketahanan Pangan di Indonesia. www.kompas.com. (Di akses, 12 November 2014).

Lembaga Penelitian UGM. 2014. Pencapaian Swasembada Pangan Tahun 2016. www.gatrra.com. (Di akses, 12 November 2014).

Wahyuni, .S. T., T. Islami, H. T. Sebayang dan B. Hariyono. 2012. Pengaruh Pupuk Hayati Petrobio dan Pupuk NPK pada Pertumbuhan Awal Tanaman Jarak Pagar (Jatropha curcas L.) 